\title{
PENGETAHUAN PUS YANG BAIK TENTANG ALAT KONTRASEPSI DALAM RAHIM (AKDR) TIDAK BERHUBUNGAN DENGAN TINDAKAN PENGGUNAAN AKDR DI DESA CINTA DAMAI KECAMATAN PERCUT SEI TUAN KABUPATEN DELI SERDANG
}

\author{
Masrah \\ Jurusan Farmasi Poltekkes Kemenkes Medan
}

\begin{abstract}
Abstrak
Indonesia memiliki masalah kependudukan dengan laju pertumbuhan penduduk yang tinggi. Upaya Pemerintah untuk menurunkan tingkat pertumbuhan adalah dengan gerakan KB yang alternatifnya melalui kontrasepsi. Alat Kontrasepsi Dalam Rahim (AKDR) merupakan metode kontrasepsi yang efektif namun kurang diminati. Penelitian ini bertujuan untuk mengetahui faktor-faktor yang berhubungan terhadap tindakan pasangan usia subur (PUS) dalam penggunaan AKDR Di Desa Cinta Damai Kecamatan Percut Sei Tuan.Penelitian ini adalah survey analitik dengan pendekatan cross sectional. Populasi pada penelitian ini adalah PUS peserta KB aktif di Desa Cinta Damai Kecamatan Percut Sei Tuan dan sampel penelitian berjumlah 88. Cara pengambilan sampel simple random sampling. Hasil penelitian menunjukkan bahwa Tingkat Pengetahuan PUS pada umumnya baik sebanyak 68,2\%, sikap PUS 37,5\%, dan Tindakan PUS terhadap penggunaan AKDR hanyak 9,1\%. Umur PUS, jenis pekerjaan, jumlah anak, tingkat pendidikan dan Sikap PUS berhubungan dengan tindakan penggunaan AKDR $(\mathrm{p}=0,000)$, sementara pengetahuan PUS tidak berhubungan dengan tindakan penggunaan AKDR $(\mathrm{p}=0,283)$. Disarankan kepada petugas penyuluh kesehatan atau kader kesehatan pada instansi kesehatan setempat yaitu puskesmas melalui posyandu dan BKKBN untuk meningkatkan promosi tentang AKDR dengan memperhatikan umur ibu, jenis pekerjaaan,jumlah anak dan tingkat pendidikan PUS.
\end{abstract}

Kata Kunci : Pengetahuan, Sikap, Tindakan, AKDR, PUS

\section{PENDAHULUAN}

\section{Latar Belakang}

Indonesia merupakan sebuah negara berkembang dengan jumlah peningkatan penduduk yang tinggi. Sebagai salah satu negara yang berkembang Indonesia tidak luput dari masalah kependudukan seperti jumlah penduduk besar dengan laju pertumbuhan penduduk yang relatif tinggi, penyebaran penduduk yang tidak merata, struktur umur muda dan kualitas penduduk yang masih harus ditingkatkan.

Upaya mengatasi masalah kependudukan tersebut dilakukan oleh banyak pihak, instansi atau departemen, lembaga, masyarakat dan lain-lain di bidang masing-masing dan secara bersama-sama. Salah satu upaya yang dilakukan oleh pemerintah untuk menurunkan tingkat pertumbuhan penduduk adalah dengan menurunkan tingkat fertilitas antara lain dengan gerakan KB Nasional bagi Pasangan Usia Subur (PUS). Adapun tujuan Gerakan KB Nasional adalah mewujudkan keluarga kecil bahagia sejahtera (NKKBS) yang menjadi dasar terwujudnya masyarakat sejahtera melalui pengendalian kelahiran dan pertumbuhan penduduk Indonesia.

Menurut WHO (Comitte Expert, 1970) dalam Sulistiyawati (2011), Keluarga Berencana adalah tindakan yang membantu individu atau pasangan suami-istri untuk mendapatkan objektif-objektif tertentu, menghindari kelahiran yang tidak diinginkan, mendapatkan kelahiran yang diinginkan, mengatur interval di antara kehamilan dan menentukan jumlah anak dalam keluarga. Agar dapat mencapai hal tersebut, maka dibuatlah beberapa cara atau alternatif, termasuk kontrasepsi atau pencegahan kehamilan dan perencanaan keluarga.

Pengetahuan mengenai pembatasan kelahiran dan Keluarga Berencana (KB) merupakan salah satu aspek penting ke arah pemahaman tentang berbagai alat atau cara kontrasepsi yang tersedia. Alat Kontrasepsi dalam Rahim (AKDR) atau disebut juga Intra-uterine contraceptive Device (IUD) merupakan salah satu jenis alat kontrasepsi jangka panjang yang ideal dalam upaya menjarangkan kehamilan. Keuntungan memakai AKDR yakni hanya memerlukan satu kali pemasangan untuk jangka waktu yang lama. AKDR juga merupakan alat kontrasepsi yang aman, karena tidak mempunyai pengaruh sistemik yang beredar ke seluruh tubuh, tidak mempengaruhi produksi ASI dan kesuburan cepat kembali setelah AKDR dilepas.

AKDR memiliki efektifitas yang tinggi dalam mencegah kehamilan. Hasil Survei Demografi dan Kependudukan Indonesia (SDKI) selama periode 1991 sampai dengan 2007 menunjukkan pola penggunaan 
kontrasepsi masih didominasi oleh kontrasepsi hormonal dan bersifat jangka pendek. Metode kontrasepsi jangka panjang seperti AKDR cenderung mengalami penurunan, yakni 13,3 persen (SDKI 1991), 10,3 persen (SDKI 1997), turun menjadi 6,2 persen (SDKI 2002-2003) dan turun lagi menjadi 4,9 persen (SDKI 2007).

SDKI 2012 menunjukkan bahwa wanita muda cenderung untuk memakai alat kontrasepsi modern jangka pendek seperti suntikan dan pil KB, sementara yang lebih tua cenderung untuk memakai kontrasepsi jangka panjang seperti AKDR dan sterilisasi wanita. Kebijakan pemerintah terhadap penggunaan AKDR adalah upaya untuk meningkatkan kesertaan KB Metode Kontrasepsi Jangka Panjang (MJKP) bagi Pasangan Usia Subur didukung dengan kebijakan dan strategi nasional secara komprehensif dan mengacu kepada Rencana Pembangunan Jangka Panjang Nasional (RPJMN) Bidang Kependudukan dan KB tahun 2010-2014 serta dengan program lainnya secara terpadu. Strategi yang dikembangkan dalam peningkatan kesertaan PUS terhadap metode kontrasepsi jangka panjang difokuskan pada kemudahan mendapatkan pilihan dan pelayanan KB secara berkualitas (BKKBN, 2011).

Berdasarkan laporan akhir tahun Badan Kependudukan dan Keluarga Berencana Nasional (BKKBN) Provinsi Sumatera Utara, jumlah Pasangan Usia Subur (PUS) pada tahun 2013 di Sumatera Utara adalah 2.184.192 PUS, akseptor KB aktifnya adalah 1.519.654 $(69,55 \%)$ dimana yang menggunakan AKDR/IUD sebanyak 161.274 (7,38\%), Metode Operasi Wanita (MOW) sebanyak $111.762(5,1 \%)$, Metode Operasi Pria (MOP) sebanyak 10.766 (0,5\%), kondom 113.348 (5,2\%), implant 169.387 (7,8\%), suntikan $497.670(22,8 \%)$ dan pil 455.447 (20,8\%).

Banyak perempuan yang mengalami kesulitan dalam menentukan pilihan jenis kontrasepsi karena terbatasnya metode yang tersedia, dan ketidaktahuan mereka tentang persyaratan dan keamanan metode tersebut. Tidak ada satu pun metode kontrasepsi yang aman dan efektif bagi semua akseptor KB. Oleh karena itu berbagai faktor harus dipertimbangkan, seperti status kesehatan, efek samping potensial, konsekuensi kegagalan dan kehamilan yang tidak diinginkan, rencana besarnya keluarga, persetujuan pasangan, norma budaya dan lingkungan bahkan persetujuan orang tua (Pinem, 2009).

Dari hasil Laporan akhir tahun 2013 Keluarga Berencana Pemberdayaan dan Perempuan (KBPP) Kabupaten Deli Serdang, jumlah PUS di Kabupaten Deli Serdang adalah 328.273 dimana yang menjadi peserta KB aktif adalah 222.778 (67,86\%). Yang menggunakan AKDR adalah sebanyak 27.519 (8,38\%), MOW 12.500 (3,80\%), MOP $1.893(0,57 \%)$, kondom $22.266(6,78 \%)$, implant 25.941 (7,90\%), suntik 63.656 (19,39\%), pil 69.003 (21,01\%). Sedangkan jumlah PUS di Kecamatan Percut adalah 77.396 PUS. Yang menjadi peserta KB aktif sebanyak 52.979 PUS sekitar 68,45\%. Dimana PUS yang menggunakan AKDR/IUD sebanyak 10.540 (13,6\%), MOW sebanyak 2.882 (3,7\%), MOP 638 (0,8\%), Kondom
$5.788(7,4 \%)$, Implant $8.120(10,4 \%)$, suntik 11.912 $(15,3 \%)$, dan pil 13.099 (16,9\%). Berdasarkan data yang diperoleh dari kantor kecamatan Percut Sei Tuan, pada bulan Mei 2014, jumlah PUS di Desa Cinta Damai sendiri adalah sebanyak 1.020 PUS. Dimana yang menjadi peserta KB aktif adalah sebanyak 725 PUS (71,07\%). Pengguna AKDR sebanyak $92(9,01 \%)$, MOW $17(1,6 \%)$, kondom 149 (14,6\%), implant $173(16,9 \%)$, suntik 150 (14,7\%), pil $144(14,11 \%)$ dan MOP (0\%).

Berdasarkan data tersebut dapat dilihat bahwa penggunaan AKDR/IUD berada pada urutan ke-lima dalam pemilihan alat kontrasepsi untuk masyarakat di Desa Cinta Damai. Adapun Desa Cinta Damai ini sendiri berada di Kecamatan Percut Sei Tuan Kabupaten Deli Serdang. Dengan batas wilayah sebelah utara berbataan dengan Desa Pulau Lalang, sebelah selatan berbatasan dengan Desa Saentis, Sebelah timur berbatasan dengan Desa Batang Kuis, sebelah barat berbatasan dengan Desa Percut. Minat PUS terhadap AKDR dipengaruhi oleh pengetahuan peserta program KB mengenai AKDR. AKDR adalah kontrasepsi yang dimasukkan ke dalam rahim yang bentuknya bermacam-macam, terdiri dari plastik (polyethylene) ada yang dililit tembaga $(\mathrm{Cu})$ bercampur perak (Ag). Selain itu ada pula yang batangnya berisi hormon progesterone (Suratun dkk, 2010). Berdasarkan uraian di atas maka penulis melakukan penelitian " Hubungan Pengetahuan dan Sikap PUS terhadap Tindakan penggunaan Alat Kontrasepsi Dalam Rahim (AKDR) di Desa Cinta Damai Kecamatan Percut Sei Tuan".

\section{Perumusan Masalah}

Berdasarkan uraian dari latar belakang di atas, maka permasalahan penelitian dapat dirumuskan dalam bentuk pertanyaan penelitian sebagai berikut: Bagaimanakah hubungan pengetahuan dan sikap PUS terhadap tindakan penggunaan Alat Kontrasepsi Dalam Rahim (AKDR) di Desa Cinta Damai Kecamatan Percut Sei Tuan.

\section{Tujuan Penelitian}

Untuk mengetahui hubungan antara umur, pekerjaan, jumlah anak, tingkat pendidikan, pengetahuan dan sikap PUS terhadap tindakan penggunaan AKDR Di Desa Cinta Damai Kecamatan Percut Sei Tuan.

\section{Hipotesis}

Ada hubungan antara antara umur, pekerjaan, jumlah anak, tingkat pendidikan, pengetahuan dan sikap PUS terhadap tindakan penggunaan AKDR

\section{Manfaat Penelitian}

1. Sebagai masukan bagi petugas puskesmas dan BKKBN dalam upaya meningkatkan jumlah akseptor KB AKDR

2. Sebagai masukan bagi peneliti selanjutnya yang meneliti berkaitan dengan KB AKDR pada PUS. 


\section{METODE PENELITIAN}

\section{Jenis dan Desain Penelitian}

Jenis penelitian bersifat analitik dengan rancangan cross sectional untuk mengetahui hubungan pengetahuan dan sikap PUS terhadap penggunaan AKDR

\section{Lokasi dan Waktu Penelitian}

Lokasi Penelitian

Lokasi penelitian dilakukan di Desa Cinta Damai Kecamatan Percut Sei Tuan.

\section{Waktu Penelitian}

Penelitian dilakukan selama dua minggu yaitu mulai awal hingga pertengahan bulan Juli 2014.

\section{Populasi dan Sampel \\ Populasi}

Populasi dalam penelitian ini adalah seluruh Pasangan Usia Subur (pasangan suami istri dimana istrinya berusia 15-49 tahun) yang mengikuti program KB di Desa Cinta Damai Kecamatan Percut Sei Tuan. Jumlah Pasangan Usia Subur (PUS) di desa Cinta Damai adalah sebanyak 1.020 pasang. Jumlah peserta KB aktif adalah sebanyak 725 pasang.

\section{Sampel}

Teknik sampling yang digunakan pada penelitian ini adalah secara acak sederhana (Simple Random Sampling), dimana setiap anggota atau unit dari populasi mempunyai kesempatan yang sama untuk diseleksi sebagai sampel (Notoatmodjo, 2010). Dalam menentukan jumlah sampel dari populasi di bawah 10.000 digunakan rumus sebagai berikut:

$$
n=\frac{N}{1+N(d)^{2}}
$$

Berdasarkan rumus di atas, dengan derajat penyimpangan sebesar $10 \%$ atau 0,1 maka diperoleh jumlah sampel sebesar 88 orang.

\section{Jenis dan Cara Pengumpulan Data Jenis Data}

Data primer dikumpulkan dari lembaran kuesioner yang diberikan secara langsung kepada respoden. Dimana kuesioner berisi pertanyaan dan dipilih jawaban yang telah dipersiapkan.
Data sekunder diperoleh dari Kantor BKKBN Provinsi Sumatera Utara, Kantor Keluarga Berencana dan Pemberdayaan Perempuan Kabupaten Deli Serdang, Kantor kecamatan Percut sei Tuan dan Kantor Lurah Desa Cinta Damai Kecamatan Percut Sei Tuan.

\section{Pengumpulan Data}

Dalam penelitian ini data tentang pengetahuan, sikap dan tindakan Pasangan Usia Subur yang mengikuti program KB diperoleh dari wawancara langsung dengan menggunakan kuesioner terstruktur.

\section{Pengolahan dan Analisis Data Pengolahan Data}

Pada penelitian ini pengetahuan, sikap dan tindakan PUS tentang Alat Kontrasepsi Dalam Rahim dianalisa secara deskriptif dan disajikan dalam bentuk tabel distribusi frekuensi.Langkah-langkah pengolahan data dilakukan melalui langkah langkah sebagai berikut: Editing (Penyuntingan Data ),Membuat Lembaran Kode (Coding Sheet),Memasukkan Data (Data Entry) dan akhirnya Tabulasi data.

\section{Analisis Data}

Analisa Data Univariat untuk mendapatkan distribusi frekuensi atau besarnya proporsi dari variabel independen dan variabel dependent sehingga dapat diketahui variasi dari masing-masing variabel

Analisis Data Bivariat untuk melihat hubungan anatara pengetahuan dan sikap Pus terhadap tindakan penggunaan AKDR dengan menggunakan uji Chi Sguare

\section{HASIL DAN PEMBAHASAN}

\section{Gambaran Umum Desa Cinta Damai Keadaan Desa Cinta Damai}

Desa Cinta Damai dikepalai oleh Bapak Sumedi, SP. Desa ini terdiri dari lima dusun, yaitu, Dusun I, Dusun II, Dusun III, Dusun IV dan Dusun V. Berdasarkan data yang diperoleh dari kantor kepala Desa Cinta Damai, Penduduk desa ini berjumlah 4.260 orang yang terdiri dari 2.379 lakilaki dan 2.241 perempuan. Dengan jumlah kepala keluarga 1.137 kepala keluarga dan jumlah Pasangan usia subur sebanyak 1020 pasang dan aktif mengikuti program KB sebanyak 725 . Kebanyakan mata pencaharian penduduk desa ini adalah wirausaha dan bertani. 
Analisis Univariat

Tabel 1.Distribusi Kharakteristik Respondem, Pengetahuan ,Sikap dan Tindakan Pasangan Usia Subur dalam penggunaan Alat Kontrasepsi Dalam Rahim (AKDR)

\begin{tabular}{|c|c|c|c|}
\hline No & Variabel & Jumlah & $\%$ \\
\hline \multicolumn{4}{|c|}{ Umur } \\
\hline 1 & $15-30$ & 40 & 45,5 \\
\hline 2 & $31-40$ & 25 & 28,4 \\
\hline 3 & $41-49$ & 23 & 26,1 \\
\hline \multicolumn{4}{|c|}{ Tingkat Pendidikan } \\
\hline 1 & Rendah & 21 & 23,9 \\
\hline 2 & Menengah & 59 & 67,0 \\
\hline 3 & Tinggi & 8 & 9,1 \\
\hline \multicolumn{4}{|c|}{ Pekerjaan } \\
\hline 1 & Ibu rumah tangga & 69 & 78,4 \\
\hline 2 & Bertani/berdagang & 16 & 18,2 \\
\hline 3 & Guru & 3 & 3,4 \\
\hline \multicolumn{4}{|c|}{ Jumlah Anak } \\
\hline 1 & $1-2$ & 49 & 55,7 \\
\hline 2 & $3-4$ & 24 & 27,3 \\
\hline 3 & $5-7$ & 15 & 17,0 \\
\hline \multicolumn{4}{|c|}{ Pengetahuan } \\
\hline 1 & Baik & 60 & 68,2 \\
\hline 2 & Cukup & 18 & 20,5 \\
\hline 3 & Kurang & 10 & 11,4 \\
\hline \multicolumn{4}{|c|}{ Sikap } \\
\hline 1 & Baik & 33 & 37,5 \\
\hline 2 & Cukup & 46 & 55,3 \\
\hline 3 & Kurang & 9 & 10,2 \\
\hline \multicolumn{4}{|c|}{ Tindakan } \\
\hline 1 & Baik & 8 & 9,1 \\
\hline 2 & Cukup & 11 & 12,5 \\
\hline 3 & Kurang & 69 & 78,4 \\
\hline \multicolumn{2}{|r|}{ Jumlah } & 88 & 100 \\
\hline
\end{tabular}

Analisis Bivariat

Tabel 2. Distribusi Umur, Pekerjaan, Tingkat Pendidikan, Pengetahuan dan Sikap Pasangan Usia Subur terhadap Tindakan penggunaan Alat Kontrasepsi Dalam Rahim (AKDR)

\begin{tabular}{|c|c|c|c|c|c|c|c|}
\hline \multirow{2}{*}{ No } & \multirow{2}{*}{ Variabel } & \multicolumn{3}{|c|}{ Tindakan } & \multicolumn{2}{|c|}{ Jumlah } & \multirow{2}{*}{ P value } \\
\hline & & Baik & Cukup & Kurang & $\mathbf{F}$ & $\%$ & \\
\hline \multicolumn{8}{|c|}{ Umur } \\
\hline 1 & $15-30$ & 5 & 1 & 34 & 40 & 45,5 & \multirow{3}{*}{0,000} \\
\hline 2 & $31-40$ & 2 & 9 & 14 & 25 & 28,4 & \\
\hline 3 & $41-49$ & 1 & 1 & 21 & 23 & 26,1 & \\
\hline \multicolumn{8}{|c|}{ Pekerjaan } \\
\hline 1 & Ibu rumah tangga & 3 & 5 & 61 & 69 & 78,4 & \multirow{3}{*}{0,000} \\
\hline 2 & Bertani/berdagang & 3 & 5 & 8 & 16 & 18,2 & \\
\hline 3 & Guru & 2 & 1 & 0 & 3 & 3,4 & \\
\hline \multicolumn{8}{|c|}{ Jumlah Anak } \\
\hline 1 & $1-2$ & 6 & 8 & 35 & 49 & 55,7 & \multirow{3}{*}{0,000} \\
\hline 2 & $3-4$ & 1 & 2 & 21 & 24 & 27,3 & \\
\hline 3 & $5-7$ & 1 & 1 & 13 & 15 & 17,0 & \\
\hline \multicolumn{8}{|c|}{ Tingkat Pendidikan } \\
\hline 1 & Rendah & 0 & 3 & 18 & 21 & 23,9 & \multirow{3}{*}{0,000} \\
\hline 2 & Menengah & 2 & 7 & 50 & 59 & 67,0 & \\
\hline 3 & Tinggi & 6 & 1 & 1 & 8 & 9,1 & \\
\hline \multicolumn{8}{|c|}{ Pengetahuan } \\
\hline 1 & Baik & 5 & 9 & 45 & 60 & 68,2 & \multirow{3}{*}{0,283} \\
\hline 2 & Cukup & 3 & 2 & 13 & 18 & 20,5 & \\
\hline 3 & Kurang & 0 & 0 & 11 & 10 & 11,4 & \\
\hline \multicolumn{8}{|c|}{ Sikap } \\
\hline 1 & Baik & 7 & 10 & 16 & 33 & 37,5 & \multirow{3}{*}{0,000} \\
\hline 2 & Cukup & 1 & 1 & 44 & 46 & 55,3 & \\
\hline 3 & Kurang & 0 & 0 & 9 & 9 & 10,2 & \\
\hline
\end{tabular}




\section{Pembahasan}

Dari hasil penelitian yang telah disajikan dapat dibuat pembahasan sebagai berikut :

\section{Analisis Univariat Karakteristik Responden}

Karakteristik responden yang berjumlah 88 orang diperoleh dari hasil wawancara meliputi Umur, Pendidikan, Pekerjaan dan Jumlah anak. Pengetahuan, Sikap dan Tindakan PUS dalam penggunaan AKDR dapat dilihat dari tabel 1. Analisi Univariat

Distribusi Frekuensi Responden kelompok umur 15 - 30 tahun yaitu sebanyak 40 orang $(45,5 \%)$. Hal ini menunjukkan bahwa kelompok usia 15 - 30 tahun merupakan umur yang terbaik bagi ibu untuk melahirkan, mengatur dan menjarangkan kehamilan.

Distribusi frekuensi tingkat pendidikan responden yang terbanyak ada dalam tiga tingkatan yaitu Rendah sebanyak 21 orang $(23,9,7 \%)$, Menengah 59 orang $(67,0 \%)$ dan Tinggi sebanyak 8 orang $(9,1 \%)$.

Distribusi frekuensi pekerjaan responden yang tertinggi adalah ibu rumah tangga yaitu 69 orang $(78,4 \%)$. Pekerjaan umum responden lainnya yaitu bertani/berdagang 16 orang $(18,2 \%)$ dan guru 3 orang $(3,4 \%)$.

Distribusi frekuensi jumlah anak, dimana jumlah anak 1-2 orang sebanyak 49 responden $(55,7 \%), 3-4$ orang $24(27,3 \%)$ responden, dan 5-7 anak 15 responden $(17,0 \%)$. Disini dapat dilihat pada umumnya responden memiliki jumlah anak $1-2$ orang.

Distribusi frekuensi pengetahuan responden terhadap AKDR dengan tingkat Pengretahuan Baik 60 orang $(68,2 \%)$, tinkat pengetahuan Cukup 46 orang $(55,3 \%)$ dan tingkat pengetahuan Kurang 9 orang (10,2\%). Distribusi sikap responden terhadap AKDR dengan tingkat Sikap Baik 33 orang (37,5\%), Cukup 46 orang $(55,3 \%)$ dan Kurang 9 orang $(10,2 \%)$

Distribusi Tindakan responden dengan tingkat Tingkat Tindakan Baik 8 orang (9,1\%), Cukup 11 orang $(12,5 \%)$ dan Kurang 69 orang $(78,4 \%)$

\section{Analisis Bivariat}

Dari hasil analisis bivariat tabel 2 menunjukkan bahwa ada hubungan yang signifikan antara Umur PUS dengan Tindakan penggunaan AKDR di Desa Cinta Damai Kecamatan Percut Sei Tuan Kabupaten Serdang Bedagai dengan nilai $0=$ 0,000 . Hal ini sesuai dengan penelitian yang dilakukan oleh Nawirah dkk tentang Faktor Yang Mempengaruhi Pemilihan Kontrasepsi IUD di Wilayah Kerja Puskesmas Wonomulyo Kecamatan Wonomulyo Kabupaten Polman dengan hasil terdapat hubungan significant antara Umur dan pemilihan kontrasepsi IUD dengan nilai $\mathrm{p}=0,000$

\section{Pekerjaan, jumlah anak, Tingkat Pendidikan dan Sikap}

Dari hasil penelitian menunjukkan bahwa ada hubungan yang signifikan antara pekerjaan, Jumlah Anak, Tingkat Pendidikan dan Sikap bagi PUS dengan tindakan penggunaan AKDR di Desa Cinta
Damai Kecamatan Percut Sei Tuan Kabupaten Serdang Bedagai dengan nilai masing-masing $p=0,000$. Hal ini sesuai dengan penelitian Ediana (2002) tentang Beberapa faktor yang Berhubungan Dengan Pemakaian Alat Kntrasepsi Pada Ibu PUS Di Desa Hargorejo Kecamatan Kokap Kabupaten Kulon Progo DIY, yang menyatakan ada hubungan pendidikan (p 0,028), Jumlah Anak (p 0,038), Pengetahuan tentang IUD ( $p$ 0,028) Sikap tentang IUD ( p 0,020), Keluarga (p 0,04), Teman (p 0,01) dengan pemakaian alat kontrasepsi.

\section{Pengetahuan}

Dari hasil penelitian menunjukkan bahwa tidak terdapat hubungan yang signifikan antara pengetahuan PUS dengan tindakan penggunaan AKDR di Desa Cinta Damai Kecamatan Percut Sei Tuan dengan nilai $p=0,283$. Hal ini mungkin saja dikarenakan sikap respondenlah yang lebih dominan dalam mempengaruhi tindakan PUS untuk menggunakan AKDR di Desa Cinta Damai Kecamatan Percut Sei Tuan Kabupaten Deli Serdang.

\section{SIMPULAN DAN SARAN}

Berdasarkan hasil penelitian dan pembahasan yang dilakaukan, dapat diambil kesimpulan sebagai berikut :

\section{Simpulan}

1. Umur responden 15 - 30 tahun merupakan umur yang terbaik bagi ibu untuk melahirkan, mengatur dan menjarangkan kehamilan

2. Tingkat pendidikan responden adalah Tingkat Menengah yang paling banyak

3. Pekerjaan responden yang paling banyak adalah Ibu Rumah Tangga

4. Jumlah anak responden masih memenuhi kriteria keberhasilan program BKKBN yaitu 1-2 orang

5. Ada hunbungan yang signifikan antara Umur, Pekerjaan, Jumlah Anak, Tingkat Pendidikan dan Sikap PUS terhadap Tindakan Penggunaan AKDR di Desa Cinta Damai Kecamatan Percut Sei Tuan Kabupaten Serdang Bedagai dengan nilai $\mathrm{p}=0,000$

6. Tidak terdapat hubungan yang signifikan antara Pengetahuan PUS terhadap Tindakan Penggunaan AKDR di Desa Cinta Damai Kecamatan Percut Sei Tuan Kabupaten Serdang Bedagai dengan nilai $\mathrm{p}=0,238$

Saran

1. Kepada tenaga kesehatan harus lebih meningkatkan penyuluhan tentang $\mathrm{KB}$ terutama KB AKDR.

2. Kepada Puskesmas terdekat diharapkan dapat memberi pelayanan dan fasilitas yang memadai bagi masyarakat yang ingin menggunakan AKDR 


\section{DAFTAR PUSTAKA}

Anggraini, Y dkk., 2012. Pelayanan Keluarga Berencana. Yogyakarta: Rohima Press.

Aspuah, S., 2013. Kumpulan Kuesioner dan Instrumen Penelitian Kesehatan. Yogyakarta: Nuha Medika.

Badan Pusat Statistik 2012. Survey Demografi dan Kesehatan Indonesia Laporan Pendahuluan <http:www.indonesia deals.com/pdf/download/www_bkkbn_go_idlitbang-pusdu-Hasil Penelitian-SDKI2012Laporan Pendahuluan SDKI2012.pdf>[diakses tanggal 15 mei 2014]

BKKBN, 2013. Buku Panduan Praktis Pelayanan Kontrasepsi. Jakarta: Bina Pustaka Sarwono

http://eprints.Undip.ac.id/6152/1/1508/pdf

http://respiratory.unhas.ac.id/bitstream/hndle/12345789/10 707/NAWIRAH\%2011112605.pdf?sequence-1

Meliani, N dkk., 2010. Pelayanan Keluarga Berencana. Yogyakarta: Fitramaya.

Notoatmodjo, S., 2010. Ilmu Kesehatan Masyarakat. Jakarta: Rineka Cipta.

Notoatmodjo, S., 2010. Metode Penelitin Kesehatan. Jakarta: Rineka Cipta.
Pinem, S., 2009. Kesehatan Reproduksi dan Kontrasepsi. Jakarta: TIM.

Nurwahida.Lilik., 2011. Gambaran Pengetahuan, Sikap dan Prilaku Ibu Usia Subur Tentang AKDR Dalam Program Keluarga Berencana di Kelurahan Ciujung Timur. http://www.perpust.fikik.uinjkt.ac.id/file.../RISET \%0NURWAHIDA.pdf [diakses tanggal 22 juli 2014]

Pinem, S., 2009. Kesehatan Reproduksi dan Kontrasepsi. Jakarta: TIM

Puspitasari, D., dan E. Winarni., 2011. Kajian Implementasi kebijakan Penggunaan Kontrasepsi IUD. Jakarta Timur. Pusat Penelitian dan pengembangan KB-KS. http://www.bkkbn.go.id/litbang/pusna/dataPB \% 20Diah_edit.pdf [diakses tanggal 15 Mei 2014]

Sugiyono, 2008. Metode Penelitian Kuantitatif Kualitatif dan R\&D. Bandung: Alfabeta, cv.

Sulistyawati, A., 2011. Pelayanan Keluarga Berencana. Jakarta: Salemba Medika. 